УДК $811.161 .1+808.1$

\title{
Rumors: a Traditional Motif and Image in the Fictional Worldview
}

\author{
Elena V. Osetrova* \\ Krasnoyarsk State Pedagogical University \\ named after V.P. Astafiev \\ 89 Ada Lebedeva Str., Krasnoyarsk, 660049, Russia
}

Received 20.12.2015, received in revised form 24.01.2016, accepted 01.03.2016

One of the traditional images of the Russian linguistic worldview is reconstructed in the article. Based on the material of historical-detective novels about Erast Fandorin by B. Akunin and by the means of semantic analysis, three metaphorical patterns of rumors that significantly diversify the fictional world of the author were identified.

The first one creates a movable picture of the physical movement of a living being or a liquid element, which, with varying degrees of activity captures the space ("rumors circulate / go / leak"). The second one is based on the idea of the extensive and intensive sound signal with a fixed source and spread limits, but, sooner or later, it always becomes silent ("Moscow was buzzing"; "they rustled in Europe"). The third one is controversial, it is either based on the understanding of rumors as a global and comprehensive speech act, which active subject is the whole space of communication ("the whole Paris speaks"), or reduces their process to a specific work of tongue as an instrument of oral speech ("evil tongues say").

These patterns are absolutely transparent in the semantic and formal-linguistic version: they are based on the reinterpretation of one phase of rumors spread - Transmitting - and exist within simple sentences.

In addition, such a review of the philological literature on the subject has revealed the researchers' attention to rumors as the working mechanism of the fictional plot, as well as to their communicative nature. The large number of modern literary scholars and linguists are motivated by this double interest.

Keywords: rumors, linguistic worldview, connotation, metaphor, metonymy, pattern, fictional image, plot mechanism.

DOI: 10.17516/1997-1370-2016-9-3-695-704.

Research area: philology.

\section{Introduction}

Rumors have been used by the human community for a long time to transmit anonymous news. More precisely, their main function lies in mass, originally oral dissemination of relevant information, the authorship and authenticity of which are not identified and no one bears responsibility for it.

It is a specific phenomenon of communication - traditional, even archaic, based

(C) Siberian Federal University. All rights reserved

* Corresponding author E-mail address: osetrova@yandex.ru 
on thousands of years of history (Dmitriev, 1995, p. 5; Shcherbatykh, 2007, p. 204), and simultaneously an active element in the model of the modern society (Osetrova, 2007, p. 48-54). In the English contexts rumors and appositional phenomena are described by the several synonymous lexemes - rumor, gossip, whisper, buzz and "grapevine".

Since the $20 \mathrm{~s}$ of the $20^{\text {th }}$ century rumors have been actively studied by European, American, and since the late 80 s by the Russian researches. The context of this analysis is very wide: philosophy, sociology, communication theory, the theory of political technologies, advertising and management (see detailed review in [Osetrova, 2013]). Each of these sciences thoroughly and deeply studies the selected subject field, developing in the direction of teaching practice (Borisova, Vasilenko, 2014), however, giving the leading position to two traditions history (Pyankevich, 2014) and social psychology (Gorbatov, 2012).

\section{Philological Tradition of Studying Rumors}

In general philology Y.V. Rozhdestvensky, in the late $70 \mathrm{~s}$ of the 20th century, pointed out rumors as a scientific object, and spoke of them in the broader context of talks (Rozhdestvensky, 1979). Two decades later, V.V. Prozorov returned to the subject, calling it promising for the whole complex associated disciplines: sociolinguistics, psycholinguistics, folklore studies and, specifically, literary studies (Prozorov, 1998).

Generally, studies of literary scholars stand apart in the list of philological works devoted to rumors. They study rumors in the aspects of fictional poetics, stylistics and ideology of work, exposing them to the subtle philological analysis since the publication of "The Plot of "Woe from Wit” (Tynyanov, 1969, p. 347-379).
Rumors are an important element of the literary texts by Beaumarchais and Cervantes, Griboyedov and Pushkin, Bulgakov and Zoshchenko, Dombrovsky and Suvorov: a list of them, extended by memoir literature includes more than a dozen of classical and contemporary authors. Someone makes rumors a full-fledged "participant" of events, an almost independent force that affects the fates and lives of the characters. And in somebody's works the problem is posed on a lesser scale: then they are transformed into a simple method of introducing new information or a plot twist. Anyway, talks / rumors often become "the object of imaginative implementation" (Prozorov, 1998, 77), implementing informative, characterizing and, finally, plot-forming functions.

In this regard the works by N.V. Gogol are, perhaps, awarded with the most careful scientific attention.

From the middle of the first decade of the 21rd century, there is an intense interest in the topic of "rumors / gossips" in Gogol's work, which generated some serious works, including dissertation researches (Vysotskaya, 2008; Nikolaeva, 2008; Solivetti, Internet resource). Referring to the earlier ideas of V.N. Voloshinov and A. Sinyavsky (Voloshinov, 1995, p. 177; Tertz, 1981, p. 420), scholars study rumors and gossips in the aspect of "effectiveness of word" that changes the fates of the characters of Gogol's novels and comedies, and as a plot mechanism which, for example, in "Dead Souls" works in the information space, parallel to the main knot of the novel.

It is indicative that C. Solivetti, the author of the large opus "Gossip as a Heraldic Construction (Mise en Abyme) in "Dead Souls", carrying out thorough literary analysis, at the same time goes beyond it. From time to time invading the area of communication science, she shows how well the author had recreated the structure and the 
purpose of rumor channel, anticipating modern sociolinguistic studies (Solivetti, Internet resource, p. 5).

Thus, at this stage of reasoning, we have the closed circle of problems. Rumors, revealed as a subject for observation a hundred years ago by history, and then by social psychology, which finally became applicable for philology, inevitably attract attention to their a) sociocommunicative and b) substantial nature of almost every researcher, regardless of his/her professional affiliation.

The latter statement is true for linguistic works as well. Linguists are ready to make the rumors, "interwoven into the fabric" of a fictional work, a full-fledged scientific object, on the one hand, studying them as a communicative phenomenon, and on the other - as an accentuated substantial fragment of the Russian linguistic worldview. Moreover, some authors are motivated by this double interest (Kreidlin, Samokhin, 2003; Osetrova, 2003; Dolgaya, 2000; 2002).

\section{Rumors in Linguistic and Fictional Worldview}

Virtually the entire population, as noted above, is involved in rumors functioning and, consequently, as a separated element of modern communication space (Osetrova, 2007. p. 4852), they should be interpreted by the national linguistic consciousness and reflected in the language and linguistic worldview.

Relevance of the selected analysis direction reconstruction of the linguistic representations about rumors - is highlighted by the fact that a similar object has already been in the focus of scientific attention. In the dictionary entry "Talks" (Prospectus "Russian Thesaurus "The World of Man and Man in the World around Him"), the concept and its verbal and semantic environment - "small concepts" are described within the boundaries of 19 semantic zones
(Prospect..., 2004, p. 62-67). Talks are defined by the authors as a leading concept of the World VI, created by the mind and the spirit of man, the highest in the hierarchy he built (Prospect..., 2004).

Rich composition of illustrative examples that fused together the texts by Virgil and Tacitus, Russian classics and contemporary authors, the "Explanatory Dictionary of the Live Great Russian Language" by V.I. Dahl and the publications of the Russian media, lead to the conclusion of the internal contradiction of the concept: talks, accompanied by chatter, news, fame, chitchats, buzz, grapevine, slanders, retellings, tales and, of course, rumors may be false and true, spontaneous and intentional, intense and hardly smoldering, local and comprehensive, spreading easily not only in domestic, but also in power, secular and sacred areas.

The undertaken experience gives a lot to understand this traditional type of oral communication.

However, the main methodological principle (conceptocentric), and the genre of the entry are characterized by abstraction and static nature of the analysis: the focus is made on the calculation of semantic valencies of the concept: 'to be'; 'who'; 'what'; 'what sort of'; 'which one'; 'how'; 'how much'; 'action'; 'state'; 'cohesion'; 'what for' and 'why'.

We propose to focus on the dynamic side of the image of rumors, and texts describing the relevant phenomena. On the one hand, this image is fairly objective, as it reflects the process of rumors spreading, and therefore, the reality itself. On the other hand, it indicates the way it is transformed in the linguistic consciousness: which its parts, for example, are the most important, which are pushed into the background and which are constructed again. "The relation of language to the extralinguistic reality is one of the fundamental problems $<\ldots>$ Language creates 
its own world. At the same time it raises the question of the degree of adequacy of the world created by the language and the world, existing independently of the language, laying beyond its limits" (Lotman, 1992, p. 8).

It is even more interesting to look at the reflection of the targeted situation in the individual author's worldview. First of all, because the writer, making more or less precise linguistic worldview, at the same time has a particular vision of reality that possesses such qualities as intensity, attention and depth, detecting such details that an ordinary language speaker may not notice. In linguistic literature there are many examples of such descriptions, particularly in the poetic material; see in particular (Agabekova, 2002, p. 112-127; Til'man, 2002, p. 491-499; Zaliznyak, Levontina, Shmelev, 2005), and references on the subject in (Prospect..., 2004, p. 68-135).

It is widely believed that such reconstructions, in addition to reflecting ideology and aesthetics of each author, specify national linguistic worldview. In R. Barthes works, for example, the subjectivity of the author's "I" in a literary text is nothing more than the "universality of stereotypes" (Barthes, 2001, p. 37). And Y.M. Lotman for an adequate understanding of the inordinate to the language reality - the outer world - considers it necessary to use the facts of different cultural languages (including the language of literary works), that are "mutually necessary to each other due to the inability of each of them to express the world individually. These languages both overlap, reflecting the same in different ways, and are located in "one plane", forming inner boundaries therein" (Lotman, 1992, p. 9-10, 92).

On the basis of the above information the research objective of this work is to analyze the dynamic aspect of the image of the rumors in the individual author's worldview.

\section{Images of Rumors}

Historical-detective novels by B. Akunin composing the series of "The Adventures of Erast Fandorin" ( "Azazel”, "Leviathan", “The Jack of Spades", "The Decorator", "The State Counsellor", "The Coronation", "The Lover of Death", etc.), where rumors are an important mechanism of the plot were chosen as empirical material; for example:

Russian original Translation into English
Про Князя Сенька, само собой, слыхал $<\ldots>$ Про Князя кто ж не слыхал? Самый рисковый на всю Москву налетчик. На рынках про него говорят, в газетах пишут («Любовник Смерти»).
Of course, Sen'ka has heard about the Prince $<\ldots>$ Who hasn't heard of Prince? He was the daredevil hijacker in Moscow. He is spoken about at the markets, and written about in newspapers ("The Lover of Death").
The main way to describe rumors in this case is standard. The stages of their distribution (the phase of Transmission) are represented isomorphic to reality by verbs, nouns and other lexical means at their standard meanings.

Meanwhile figurative way to display the process can also be applied, and in this case the connotative aspect becomes operating.

In the connotative aspect, not emotiveexpressive function such as the speaker's evaluation of the world is paramount for us (Telia, 1988), but the range of language associations and original metaphoric images (Uspensky, 1979). N.D. Arutyunova (Arutyunova, 1976, p. 93-111) and V.N. Telia (Telia, 1981) analyze figurative connotations of the names of feelings and the names of mental semantics in their works that became exemplary long time ago.

According to V.N. Telia, figurative metaphor "can be embodied in a single word, but more often $<\ldots>$ it is a holistic artistic canvas or a sketch with its idea, composition and colors" 
(Telia, 1988, p. 198). Understanding of this helps to identify a number of connotative images for rumors dissemination. It is as if superimposed by the external situation turned into a transparent "picture"-prism, through which the author of the work casts a glance at the desired fragment of the linguistic worldview.

So, the metaphor of movement should be recognized as the most demanded; see examples:

\section{Russian original}

Все исполнено

$<\ldots>$ Слух [о дуэли] пущен («Алмазная колесница-2»);

Ходят самые разные слухи. Суга не застрелился, даже не совершил харакири. Он избрал древний изуверский способ ухода из жизни («Алмазная колесница-2»); По Москве ходят странные слухи о какой-то волшебной черной птице, которая слетела с небес к статскому советнику Еропкину, вручила ему златое кольцо и говорила с ним человеческим голосом («Пиковый валет»).

Information movement can be not only usual and regular, but marked by varying degrees of intensity; compare:

\section{Russian original}

Translation into English

По Москве поползли слухи. Якобы завелся в городе оборотень (Декоратор);

Еще в обед по лагерю поползли какие-то нехорошие слухи («Турецкий гамбит») и

Вести тут разносились быстро. Не прошло
A rumor ran through Moscow, as if there is a werewolf in the city ("The Decorator"). Some nasty rumors ran through the encampment at lunchtime ("The Turkish Gambit"). and

News travel fast here. Less than in two hours и двух часов после ухода сан-стефанских посетителей, а к Акпаше уже прибыла депутация греческих торговцев из самого Константинополя («Турецкий гамбит»). after San Stefano visitors left, a deputation of the Greek merchants from Constantinople itself arrived to Ak Pasha ("The Turkish Gambit").

Information holders are conceived in the image of a living being that is apparently subordinated to man and move independently or with someone's help: mostly rumors, and, in addition to them messages, news, stories, tales, assumptions, legends and folk tales (nominative case $\left.-\mathrm{N}_{1}\right)$ :

\section{Russian original}

«Крадущиеся»

славились тем,

что очень ловко

использовали в своих

целях животных:

почтовых голубей, охотничьих ястребов, даже пауков, лягушек и змей. Отсюда и пошли легенды о том, что они умеют превращаться в любую тварь («Алмазная колесница-2»); Судя по тому, что о Тамбе ходили подобные сказания, репутация у него и в самом деле была легендарная («Алмазная колесница-2»); Об этом кровавом торжестве японцев проносились по Европе лишь первые, тревожные, глухие вести («Алмазная колесница-1»).

\section{Translation into English}

The "furtives" were famous for their skillful use of animals for their purposes: pigeons, hunting hawks, even spiders, frogs and snakes. Hence started the legends that they are able to transform into any creature ("The Diamond Chariot-2");

Judging by the fact that such tales circulated about Tamb, he really had a legendary reputation ("The Diamond Chariot-2");

Only the first, anxious, vague news about this bloody triumph of the Japanese swept across Europe ("The Diamond Chariot-1").
In addition to land movement, Transmission in B. Akunin's writings is associated with the liquid that initially leaks into outer space, and then flows into one point: 


\section{Russian original}

Конечно, та история была сохранена в тайне от широкой публики, но кое-какие слухи в европейскую прессу все же просочились («Пиковый валет») К Жюли стекались сведения самого

Translation into English

Of course, that story

was kept secret from the general public, but, nevertheless, some rumors leaked to the European press ("The Jack of Spades"). Information of different kinds, including that, very important for the party, flew to Julie ("The State Counsellor"). числе очень важные для партии («Статский советник»).

The metaphor of movement is embroidered by visual and sound connotations that the author associates with the perception of the moving creatures and expressed by adjectives; compare: bad, nasty rumors and vague news.

Another figurative prism through which the author considers the Process of anonymous information dissemination shifts the reader to the space of sound. Its source may come from someone who was interpreted as a newsmaker:

\section{Russian original Translation into English}

Егора Тишкина всякий Everyone knew Egor знал. И кровь отворить, Tishkin. He could и мозолю срезать $<\ldots>$ А знатнее всего по теломятному делу гремел («Пиковый валет»). stop the blood and cut the corn $<$... $>$ But the fame resounded for his massage therapy ("The Jack of Spades").

But in most cases, the emphasis is shifted to the signal propagation medium:

\section{Russian original}

Воображение

барышень было всецело поглощено сенсацией, о которой гудела вся Первопрестольная. Полиция наконец захватила знаменитую шайку «лихачей»
(«Алмазная

колесница-1»);

Весь пароход гудит, но подробности пока мало кому известны («Левиафан»). demons" ("The Diamond

Chariot-1");

The whole ship is buzzing, but the details are still little-known ("Leviathan").

Language consciousness also represents such a structure of the situation when the sound source is not relevant at all; in this case the action is described by the verb in impersonal form or by the verbal noun compare:

\section{Russian original}

О Боевой Группе зашумели в Европе («Статский советник»)

Шуму, звону,

разговоров о

лужниковском стыке

было на всю Хитровку («Любовник смерти»).

\section{Translation into English}

They started rustling about Battle Group in Europe ("The State Counsellor"). Whole Khitrovka was full of noise, gossips and talks about the Luzhniki meeting ("The Lover of Death").

Despite the expanse (all, whole, full) and the intensity of this sound (the semantics of verbs), sooner or later it fades away:

\section{Russian original}

Какое-то время циркулировали слухи о всемирном заговоре не то масонов, не то евреев, не то и тех и других вместе взятых и поминали господина Дизраэли, но потом как-то утихло («Азазель»).

For an overview of the Process methaphorics the described lexis is summarized in the Table 1.

The image of rumors as an inclusive speech act finishes this series:

Russian original

Сегодня, 16 марта, весь Париж только и говорит, что о леденящем кровь преступлении,

\section{Translation into English}

For some period of time there were rumors about a global conspiracy either the Masons, or the Jews, or both together and they recollected Mr. Disraeli, but then it somehow subsided ("Azazel"). 
нарушившем

чинное спокойствие

аристократичной рю де

Гренель («Левиафан»);

Про них [шайку

«пиковых валетов»]

вся Москва говорит

(Пиковый валет);

Вся Италия обсуждает дуэль, состоявшуюся между генералом

Андреотти и депутатом

Кавалло (Декоратор»);

О нас говорит весь

город! («Любовница

Смерти»).

Rue de Grenelle

("Leviathan").

All Moscow speaks about them [the gang of "The Jacks of Spades"] ("The Jacks of Spades").

All Italy is discussing

a duel that took place between General

Andreotti and deputy

Cavallo ("The

Decorator");

The whole city speaks

about us! ("The Lover of Death").

The degree of vividness in this case is, of course, reduced in comparison to the previous two cases, since the verb speak is included in the number of the language standards of Transmission. The source of figurativeness is hidden not in the metaphor, but in the embodying metonymy: the role of the subject who transmits the information is attributed to an environment where population itself acts as a mass transmitter of rumors.

However, their metonymical interpretation could be turned in the opposite direction, and in this case tongue is endowed with the active function of the Transmitter:

\section{Russian original}

Злые языки утверждали, что отсутствие ее высочества на
Translation into English

Evil tongues asserted that Her Majesty's absence on Moscow celebrations are московских торжествах explained not so much объясняется не столько by maternal love as the материнской любовью, reluctance to play the сколько нежеланием role of dummy at the исполнять роль young queen's triumph статистки при триумфе (“The Coronation"); молодой царицы («Коронация»);

Злые языки поговаривали, что Британия просто решила прибрать к рукам сокровища Багдассара («Левиафан»).

It is easy to see how the image of the speaker or either expanded to the size of the medium of the information dissemination (Italy) or shrinks to the size of negatively perceived language "instrument" (tongue).

The image is complemented by the similar metonymical interpretation of the phase of acquiring information (the phase of Existence); compare with the previous:

\section{Russian original}

Я препотешный выдумал для врачишек этих $<$.. > Завтра

Москва животики надорвет, как узнает («Декоратор»). кундштюк один

\section{Translation into English}

I have made the funniest dodge for these lousy doctors $<\ldots>$ Tomorrow Moscow will laugh its head off when it finds out ("The Decorator")

\section{Conclusion}

Thus, describing the process of rumors spreading in his novels, B. Akunin makes three

Table 1. Metaphorical Images of Process (the phase of Transmission)

\begin{tabular}{|c|c|c|c|c|}
\hline Images & Land movement & Movement of liquids & Sound signal & Visual image \\
\hline Lexis & started & leak & speak & dark \\
& circulate & flew & resounded & turbid (news) \\
& reached & & rustle & \\
& went & & buzz & \\
& run & & subside; & \\
& travel & & & \\
& swept & & & \\
& & & & \\
& & & & \\
\end{tabular}


patterns that diverse this traditional image of fictional model of the world.

The first one creates a dynamic picture of physical movement of a living being or a liquid element, which captures space with varying degrees of activity (rumors circulate, go and leak). The second one is based on the idea of the extensive and intensive sound signal with a fixed source and spread limits, but, sooner or later, it always fades away (Moscow was buzzing; they rustled in Europe). The third one is controversial, it is either based on the understanding of the Process as a global and comprehensive speech act, which active subject is the whole space of communication (the whole Paris speaks), or reduces their process to a specific work of tongue as an instrument of oral speech (evil tongues say).

These patterns are absolutely transparent in the semantic and formal-language versions: in practice they are based on the interpretation of one phase of rumors dissemination Transmission, and exist within simple sentences: denominative or two-member (constructive schemes $\mathrm{N}_{1}$ and $\mathrm{N}_{1} \mathrm{~V}_{\text {fin }}$ ).

Against the background of linguistic transparency and, perhaps, due to it, there is an understanding of the scale and intense colors of the final picture. In addition to the content of the language images, this scale is supported by syntax (structure with quantitative value - noise, buzz), as well as verbal and nominative lexis (resounded, rustle, run, disseminated, swept; Moscow, Paris, Italy, Europe); the list is complemented by specific lexis with the semantics of the intensive dissemination of rumors (persistent, so much, fast, momentary, instantly, in a moment), lexis with the semantics of the information diversity (variety of rumors, different rumors) and its importance (very important information).

\section{References}

Agabekova, K.N. (2002). Kontsept "dusha" v individual'no-avtorskoi iazikovoi kartine mira B. Okuddjavy [Concept "Soul" in Individual-Author's Worldview of B. Okudzhava], in Okudzhava: Problems of Poetics and Textology, M., 112-127.

Arutyunova, N.D. (1976). Predlozhenie i smysl [Sentence and Meaning], M., Nauka, 384 p.

Barthes, R. (2001). $S / Z$, M., Editorial URSS, 232 p.

Borisova, E.G., Vasilenko, S.A. (2014). Osnovy rumologii: Teoria i praktika upravleniia slukhami: Uchebnoe posobie dlia magistratury [Rumorology Fundamentals: Theory and Practice of Rumors Management: Study Guide for Master Course], M., Flinta: Nauka, 132 p.

Voloshinov, V.N. (1995). Philisophia i sotsiologiia gumanitarnykh nauk [Philosophy and Sociology of Arts], SPb., Asta-Press, 380 p.

Vysotskaya, V. (2008). Slukhi, tolki i spletni v kontekste proizvedenii Gogolia [Rumors, Talks, Gossips in the Context of Gogol's Works], in Seventh Gogol's Readings: Gogol and Folk Culture: Collected Materials of Reports and Presentations, M., CheRo, 252-260.

Gorbatov, D.S. (2012). Psikhologia slukhov i spleten: monographiia [Psychology of Rumors and Gossips: Monograph], SPb., Rech, 233 p.

Dmitriev, A.V. (1995). Slukhi kak ob'ekt sotsiologicheskogo issledovaniia [Rumors as an Object of Sociological Research], in Sociological Research, 1, 5-11.

Dolgaya, T.A. (2000). Kontsept slukhov v russkoi kul'ture [The Concept of Rumors in Russian Culture], in Basic Higher Education: Didactics and Linguistics Issues, Volgograd, 1, 95-100. 
Dolgaya, T.A. (2002). Slukhi kak vid massovoi informatsii [Rumors as a Type of Mass Information], in Basic Higher Education: Didactics and Linguistics Issues, Volgograd, (2), 113-117.

Zaliznyak, A.A., Levontina, I.B., Shmelev, A.D. (2005). Kluchevye idei russkoi yazikovoi kartiny mira [Key Ideas of Russian Linguistic Worldview], M., Yazyki slavianskoi kul'tury, 544 p.

Kreidlin, U.E., Samokhin, M.V. (2003). Slukhi, spletni, molva - garmoniia i besporiadok [Rumors, Gossips, Talks - Harmony and Disorder], in Logical Language Analysis: Cosmos and Chaos, M., Indrik, 117-157.

Lotman, Y.M. (1992). Kul'tura i Vzryv [Culture and Explosion], M., Gnozis; Publishing Group "Progress", $272 \mathrm{p}$.

Nikolaeva, P.V. (2008). Problema deistvennosti slova v khudozhestvennom mire N.V. Gogolia [The Problem of Word Efficiency in N.V. Gogol's Fictional World]: Abstract of the Candidate's Thesis in Philology [Ivanovo State University], 16 p.

Osetrova, E.V. (2003). Slukhi v rechevoi i yazykovoi deistvitel'nosti [Rumors in Speech and Linguistic Reality], in Bulletin of the Russian Academy of Sciences, 1 (62). Literature and Language Series, 49-54.

Osetrova, E.V. (2007). Prichina, tsel' i phunktsii ispol'zovaniia skukhov v massmedia [Reason, Purpose and Functions of the Use of Rumors in Mass Media], in Language. Discourse. Text: Proceedings of the $3^{\text {rd }}$ International Scientific Conference, Rostov-on-Don, UFU Publishing House, 48-52.

Osetrova, E.V. (2013). Rumours as a Subject of Scientific Analysis: Social Psychology, History, Philology in Journal of Siberian Federal University. Humanities \& Social Sciences, 6 (9), 1265-1280, available at: http://journal.sfu-kras.ru/series/humanities/2013/9

Prozorov, V.V. (1998). Molva kak philologicheskaia problema [Talks as a Philological Problem], in Philological Sciences, 3, 73-78.

Prospect: Russkii ideographicheskii slovar' "Mir cheloveka i chelovek v okruzhaushchem ego mire" [Prospectus: Russian Thesaurus "The World of Man and Man in the World around Him" (2004), edited by N.Y. Shvedova; Russian Language Institute of RAS, M., 136 p.

Pyankevich, V.L. (2014). Liudi zhili slukhami: Neformal'noe kommunikativnoe prostranstvo blokadnogo Leningrada [People Lived with Rumors: Informal Communicational Space of Blockaded Leningrad], SPb., Vladinir Dahl, 479 p.

Rozhdestvensky, Y.V. (1979). Vvedenie v obshchuiu philologiiu [Introduction into General Philology], M., Vysshaya Shkola, 224 p.

Solivetti C. Spletni kak geral'dicheskaya konstruktsiia (Mise en Abyme) v "Mertvykh Dushakh" [Gossip as a Heraldic Construction (Mise en Abyme) in "Dead Souls"] in Toronto Slavic Quarterly: Academic Electronic Journal in Slavic Studies, University of Toronto, 31, available at: http://www. utoronto.ca/tsq/30/solivetti30.shtml

Telia, V.N. (1981). Tipy yazikovykh znachenii: Sviazannoe znachenie slova v yazyke [Types of Linguistic Meanings: Connected Word Meaning in Language], M., Nauka, 223-259.

Telia, V.N. (1988). Metaphorizatsiia i ee rol' v sozdanii yazikovoi kartiny mira [Metaphorization and its Role in the Creation of Linguistic Worldview], in The Role of Human Factor in Language: Language and Worldview, M., Nauka, 173-204.

Tertz, A. (Sinyavsky, A.D.) (2002). V teni Gogolia [In the Shade of Gogol], Paris, Syntaxes, 1981, $526 \mathrm{p}$. 
Til'man, Y.D. (2002). Prostranstvo v yazykovoi kartine mira F.I. Tyutcheva (kontsept "Krug") [Space in F.I. Tyutchev's Linguistic Worldview (Concept "Circle")] in Logical Language Analysis: Semantics of Beginning and End, M., Yazyki russkoi kul'tury, 491-499.

Tynyanov, Y.N. (1969). Siuzhet "Goria ot uma" [The Plot of "Woe from Wit"] in Tynyanov, Y.N. Pushkin and His Contemporaries, M., Nauka, 347-379.

Uspensky, V.A. (1979). O veshchnykh konnotatsiiakh abstraktnykh sushchestvitel'nykh [On Material Connotations of Abstract Nouns], in Semiotics and Informatics, M., 11, 142-148.

Shcherbatykh, Y.V. (2007). Psikhologiia vyborov. Manipulirovanie massovym soznaniem: Mekhanismy vozdeistviia: Populiarnaia entsiklopedia [Psychology of Elections. Mass Consciousness Manipulation: Mechanisms of Influence: Popular Encyclopedia], M., Eksmo, 400 p.

\title{
Слухи: традиционный мотив и образ в художественной картине мира
}

\author{
Е.В. Осетрова \\ Красноярский государственный педагогический университет \\ им. В.П. Астафьева \\ Россия, 660049, Красноярск, ул. Ады Лебедевой, 89
}

В статье реконструирован один из традиционных образов русской языковой картины мира. На материале историко-детективных романов Б. Акунина об Эрасте Фандорине и с помощью семантического анализа выявлены три метафорических «эскиза» слухов, которые значительно разнообразят художественный мир автора.

Первый создает подвижную картину физического движения живого существа либо жидкой стихии, которые с разной степенью активности захватывают пространство («слухи ходят, проносятся, просачиваются»). В основе второго лежит представление об обширном и интенсивном звуковом сигнале, имеющем фиксированный источник и границы распространения, но рано или поздно всегда затихающем ("Первопрестольная гудела»; «зашумели в Европе»). Третий же противоречив - либо основан на осмыслении слухов как глобального и всеохватного речевого действия, активным субъектом которого является все пространство общения («весь Париж говорит»), либо сводит их процесс к частной работе языка как инструмента устной речи («злые языки поговаривали»).

Эти эскизы абсолютно прозрачны в семантическом и формально-языковом исполнении: практически они основаны на переосмыслении одной фазы распространения слухов трансляции - и существуют в рамках простых предложений.

Кроме того, подробный обзор филологической литературы по данной теме обнаруживает внимание исследователей к слухам как к рабочему механизму художественного сюжета, а также к их коммуникативной природе. Многие современные литературоведы и лингвисты мотивированы этим двойным интересом.

Ключевые слова: слухи, языковая картина мира, коннотация, метафора, метонимия, эскиз, художественный образ, механизм сюжета.

Научная специиальность: 10.00.00 - филологические науки. 